\title{
Identification of formalin and borax on tuna in Ngemplak market Tulungagung regency
}

\author{
Qurrotu A'yunin Lathifah ${ }^{1 a^{*}}$, Dora Dayu Rahma Turista ${ }^{1 b}$, Ludfiana Azizah ${ }^{1 c}$, Ahmad Erfan \\ Khulaifi ${ }^{1 \mathrm{~d}}$ \\ ${ }^{1}$ D3 Medical Laboratory Technology STIKes Hutama Abdi Husada Tulungagung, East Java, \\ Indonesia,
}

a21ayunin@gmail.com *

b doraturistaofficial@gmail.com

c azizahludfi16@gmail.com

d kulepstory@gmail.com

* corresponding author

\begin{tabular}{|c|c|}
\hline & \\
\hline $\begin{array}{l}\text { date: } \\
\text { th, } 2019 \\
\text { date: } \\
\text { th } 2019 \\
\text { d: } \\
2019 \\
\text { d: }\end{array}$ & $\begin{array}{l}\text { Misuse of formalin and borax is still common, including processing and } \\
\text { preserving fish. Therefore, this study aims to identify the presence of formalin } \\
\text { and borax in tuna on the market Ngemplak, Tulungagung regency. The } \\
\text { samples used in this study were fresh tuna in the Ngemplak market originating } \\
\text { from the beaches of Prigi, Sine, Tambakrejo, Popoh and Sidem. The samples } \\
\text { were tested qualitatively using the colorimetric method by Schryver reagent for } \\
\text { formalin and curcumin paper for borax. The results obtained in this study, from } \\
\text { the five tuna samples not detected contained formalin and borax which were }\end{array}$ \\
\hline 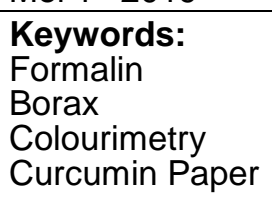 & $\begin{array}{l}\text { lor in the test. Tuna sold in the Ngemplak market } \\
\text { tively contains formalin and borax, making it safe } \\
\text { ed that the relevant office will carry out routine } \\
\text { od additives, especially preservatives circulating in } \\
\text { ic should always be careful in choosing safe food. }\end{array}$ \\
\hline
\end{tabular}

This is an open access article under the CC-BY-SA license

\section{INTRODUCTION}

Food is one of the basic human needs in survival. The food we consume must contain nutritional and nutritional value, one of which must contain protein. Fish is a food that is rich in protein. Nearly $90 \%$ of its contents are essential amino acids, ${ }^{1}$ so it is very good for us to consume. Because of limitations, fishermen usually cannot directly send their fish to the market. They preserve the fish so as not to rot quickly. 2 Preservation of fish is often done, namely salting, drying, fumigation,,-3 cooling,,-4 and the addition of preservatives.

Formalin and borax are preservatives which are prohibited for the preservation of foodstuffs, $\underline{5}$ but their abuse continues to this day. The use of formalin in fish and marine products in Indonesia is reported to have the highest rating of up to $66 \%$ of 786 samples.. Found formalin in large fish species in the city of Dhaka, Bangladesh. $\underline{7}$ Of the 12 fish species tested there were 4 species containing formaldehyde. 9 out of 41 samples of salted fish $(21.9 \%)$ in the traditional Semarang city market Indonesia have positive formalin. $\underline{2}$ fresh fish samples from 52 samples in Bandar Lampung Indonesia positively 
contain formalin. $\frac{10}{}$ Yiu found the presence of borax in fish meatballs in Bintulu, Sarawak Malaysia with concentrations from $0.86 \mu \mathrm{g} / \mathrm{g}$ to $1.58 \mu \mathrm{g} / \mathrm{g} .11$

Formalin is actually not a food additive, but formalin is often misused.? Formalin was chosen because of its low price, capable of making rubbery, undamaged, practical and effective preserving food. .2 Formalin in the body can cause respiratory tract cancer and increase the risk of leukaemia. Formalin is included in the first group of causes of cancer in the body.., 14 The human body's tolerance threshold for formalin is 0.2 milligrams per kilogram of body weight. $\frac{15}{}$

Borax or known as "bleng" (Javanese) is a white crystalline powder containing boron. Borax is used for anti-fungi, wood preservatives, and antiseptic ingredients. Consumption of foods containing borax can cause poisoning and can even cause death. Death in adults can occur if the boric acid he consumes is $15-20$ grams. $\frac{16}{\text { Therefore, this }}$ research needs to be done to identify formalin and borax in the tuna in the market, Ngemplak Tulungagung.

There are various ways of qualitative and quantitative analysis of formalin in food ingredients, including using Chromatrope, Nash, Schryver test solutions, $\underline{12}$ Fehling test $\stackrel{2}{ }$ extraction SPME, GC-MS.. Borak in food can also be analyzed by various methods, namely flame tests, titrimetry and spectrophotometry.11, 16 The presence of formalin in this study was detected by colourimetry using Schryver and borax reagents selected using curcumin paper.

\section{MATERIALS AND METHODS}

This research is a descriptive study with a cross-sectional design. This research was conducted in April 2017 at the Surabaya Health Laboratory (BBLK) large hall. The population in this study were all fresh tuna sold at the Ngemplak Tulungagung market. The sampling technique used in this study is cluster sampling.

The materials used in this study included fresh tuna, $\mathrm{HCl}$ (MERCK), $\mathrm{Na}_{2} \mathrm{~B}_{4} \mathrm{O}_{7}$ (MERCK), $\mathrm{H}_{3} \mathrm{PO}_{4}$ (MERCK), phenylhydrazine (MERCK) and $\mathrm{K}_{3} \mathrm{Fe}(\mathrm{CN})$ (MERCK), turmeric, aquadest, and filter paper. The equipment used is an analytical balance (Mettler $A E 25)$, blender, a set of glass tools, and a set of distillation devices.

\section{Formalin Test with Colourimetry}

Cut 50 grams of sample then added $100 \mathrm{ml}$ of distilled water and mashed. The fine sample was put into a distillation flask and $20 \mathrm{ml}$ of concentrated $\mathrm{H}_{3} \mathrm{PO}_{4}$ was added and distilled. The distillation results are accommodated in a $50 \mathrm{ml}$ volumetric flask. Then piped $10 \mathrm{ml}$ of distillate, added $2 \mathrm{ml}$ of phenylhydrazine $1 \%, 1 \mathrm{ml}$ of $\mathrm{K}_{3} \mathrm{Fe}(\mathrm{CN}) 1 \%$ and $5 \mathrm{ml}$ of concentrated $\mathrm{HCl}$. If the sample contains formalin, the solution will be red.

\section{Test Borax with Curcumin Paper}

Borax testing begins with making curcumin paper by taking a few pieces of medium-sized turmeric, then pounding and filtering. The filter paper is then dipped in the turmeric liquid and dried. After that, then a borax test was performed on the sample. Samples were taken to taste, mashed and then put into $100 \mathrm{ml}$ beaker glass, added aquadest to taste (to form a dilute paste mass), added $10 \mathrm{ml}$ of $4 \mathrm{~N} \mathrm{HCl}$ and homogenized. Curcumin paper is then dipped into the sample paste, then curcumin paper is placed on the plate and waited until it is dry. Observed the color change that occurs, if the sample contains borax paper will turn red.

\section{RESULTS AND DISCUSSION}

Ngemplak market is a Tulungagung agribusiness centre that is very accessible. In Ngemplak market, tuna is supplied by fishermen from various beaches around Tulungagung, namely from the beaches of Prigi, Sine, Tambakrejo, Popoh and Sidem. 
Given its perishable nature, tuna are susceptible to preservatives. The results of the identification of formalin and borax on tuna that are sold in the Ngemplak market Tulungagung can be seen in table 1 below:

Table 1. Results of Examination of Formalin and Borax Levels on Tuna in the Ngemplak Tulungagung Market

\begin{tabular}{lcc}
\multicolumn{1}{c}{ Mackarel Tuna } & Formalin Content & Borax Content \\
\hline Prigi Beach & - & - \\
\hline Sine Beach & - & - \\
\hline Tambakrejo Beach & - & - \\
\hline Popoh Beach & - & - \\
\hline Sidem Beach & - & - \\
\hline
\end{tabular}

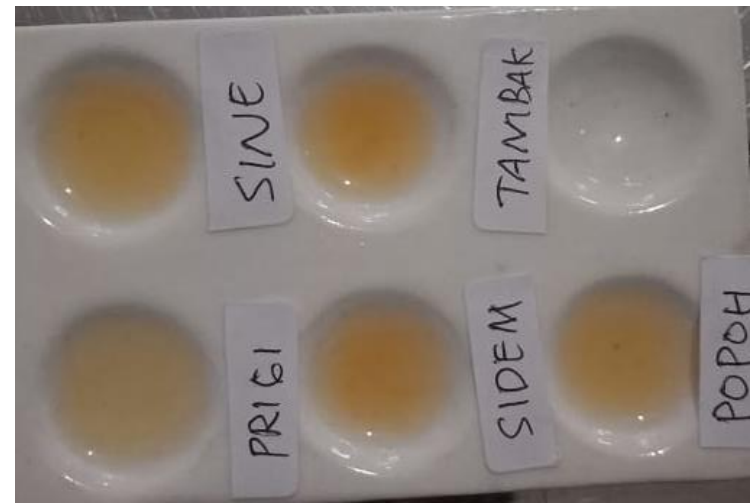

(a)

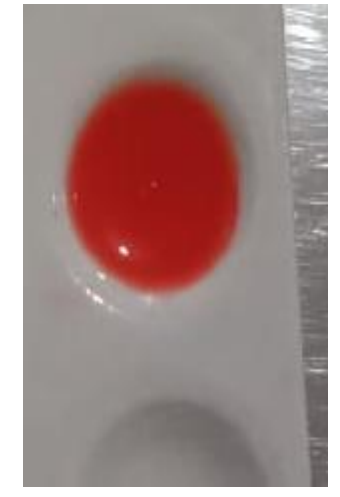

(b)

Figure 1. Results of a test of formalin in a sample (a) and positive control of formalin (b)

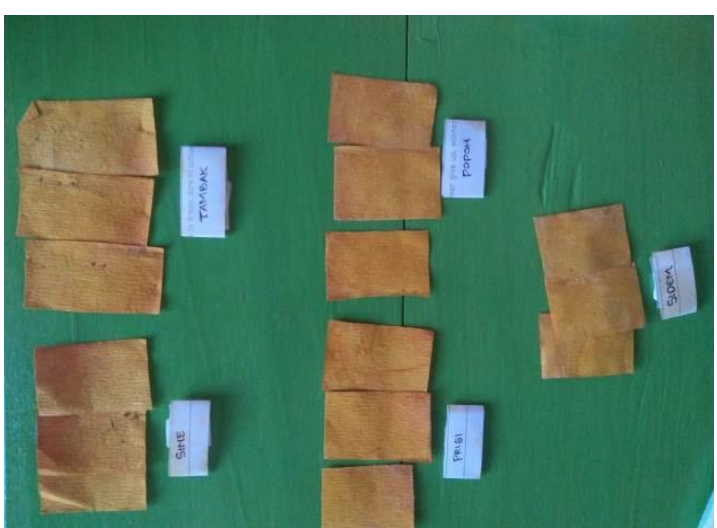

(a)

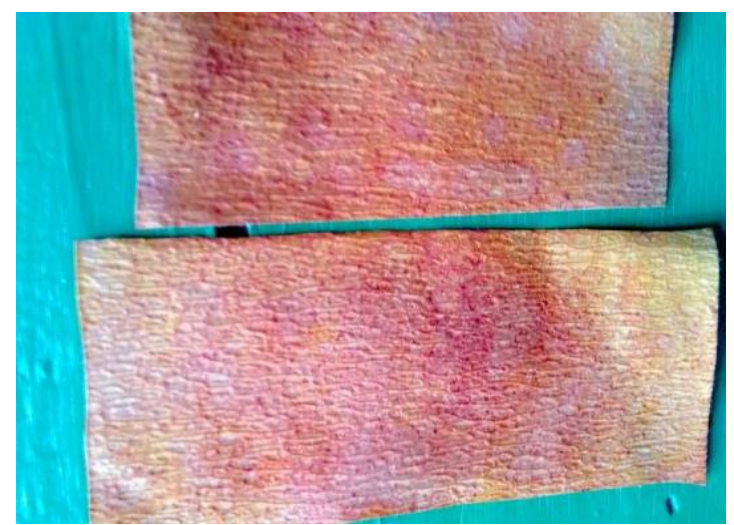

(b)

Figure 2. Results of a test of borax in a sample (a) and positive control of borax (b)

Based on the results of the tests that have been conducted it was found that the five samples did not contain formalin and borax. This is shown by not obtaining a red solution in the formalin test with colourimetry (Figure 1) and no red colour is formed in the test of borax with curcumin paper (Figure 2). 
Colourimetry using Schryver reagent was chosen in this study because based on research $\underline{12}$ Schryver reagent was the most suitable reagent for formaldehyde testing because it was easy to use and had a low detection limit. Schryver reagent will form complex compounds in red with formalin. The test results did not show any red colour in the sample added with Schryver reagent.

Curcumin in turmeric can bind with boric acid to form red boron-curcumin (rososianin) complex compounds. Therefore, turmeric can be used to detect the presence of borax in a sample. Curcumin is able to detect the presence of borax in samples up to a concentration of $0.5 \%$. $\underline{16}$ The use of $\mathrm{HCl}$ in the borax test aims to separate borax compounds from other organic compounds in tuna samples. The test results do not show any colour changes in curcumin paper, meaning that the negative sample contains borax.

The absence of formalin and borax in the sample showed that fishermen/fish sellers did not add formalin and borax in fresh tuna. The use of formalin in fish preservation is very ineffective. 17 This is because the presence of formalin in the body of the fish cannot be completely lost, but it can only decrease. Formalin-contaminated fish in principle cannot be considered a source of animal protein. The fishermen/fish seller prefer to use ice bulk to preserve fish. The use of ice blocks is quite effective considering the distance between fish suppliers and the market is not too far away, so it does not require a long time to go to the market. The distance between Ngemplak market and Sine (Kalidawir) beach is $38 \mathrm{~km}$, Popoh (Besole) beach is $29 \mathrm{~km}$, Prigi beach (Trenggalek) 45 $\mathrm{km}$, Sidem beach (Besuki) $29 \mathrm{~km}$, and Tambakrejo beach (Blitar) $58 \mathrm{~km} . \underline{18}$ The cooling method with a ratio of 1: 1 ice and fish for 6 hours still produces good organoleptic quality. $\frac{19}{-}$ Low ice temperatures can inhibit biochemical processes (autolysis) in the fish's body. Enzyme activity and decomposing bacteria in the body of the fish will decrease with these low temperatures $\underline{20}$ so that the fish will become more durable. Addition of ice bulk as a preservative for fresh fish is very common because of its low price and easy way to do it.

\section{CONCLUSIONS}

From the results of the above research, it can be concluded that tuna in the Tulungagung market (which comes from the beaches of Prigi, Sine, Tambakrejo, Popoh, and Sidem) does not contain formalin and borax, so it is safe to consume

\section{ACKNOWLEDGEMENT}

We would like to thank our gratitude to all those who have been involved and helped in completing this journal. This journal is far from perfect but is expected to be useful not only for researchers but for all readers. Building criticism and suggestions are always expected for improvement.

\section{REFERENCES}

1. Hadini, F. M. (2017). Detection System Milkfish Formalin Android-Based Method Based on Image Eye Using Naive Bayes Classifier. Matics, 9(1), 44. DOI: https://doi.org/10.18860/mat.v9i1.4054

2. Wijayanti, N. S., \& Lukitasari, M. (2018). Analisis Kandungan Formalin Dan Uji Organoleptik Ikan Asin Yang Beredar Di Pasar Besar Madiun. Florea: Jurnal Biologi Dan Pembelajarannya, 3(1), 59. DOI: https://doi.org/10.25273/florea.v3i1.789

3. GO, G., \& OA, S. (2018). Fish Processing and Preservation Techniques Selected Fishing Communities along the Upper Benue River, Taraba State. Poultry, Fisheries \& Wildlife Sciences, 05(02), 2-5. DOI: https://doi.org/10.4172/2375-446x.1000184

4. Dawson, P., Al-Jeddawi, W., \& Remington, N. (2018). Effect of Freezing on the Shelf Life of Salmon. International Journal of Food Science, 2018, 1-12. DOI: https://doi.org/10.1155/2018/1686121

5. Permenkes RI. (2012). Tentang Bahan Tambahan Pangan, Permenkes RI No. 033 
tahun

2012 ,

Jakarta.

http://farmalkes.kemkes.go.id/?wpdmact=process\&did=OTluaG90bGluaw

6. Badan Pengawas Obat dan Makanan Republik Indonesia (BPOM RI). (2010). Informasi Makanan yang Mengandung zat Berbahaya. Jakarta: BPOM RI, KOPER POM dan CV Sagung Seto.

7. Uddin, R., Wahid, M. I., Jesmeen, T., Huda, N. H., \& Sutradhar, K. B. (2011). Detection of formalin in fish samples collected from Dhaka city, Bangladesh. Stamford Journal of Pharmaceutical Sciences, 4(1), 49-52. DOI: https://doi.org/10.3329/sjps.v4i1.8866

8. Bianchi, F., Careri, M., Musci, M., \& Mangia, A. (2007). Fish and food safety: Determination of formaldehyde in 12 fish species by SPME extraction and GC-MS analysis. Food Chemistry, 100(3), 1049-1053. DOI: https://doi.org/10.1016/i.foodchem.2005.09.089

9. Habibah, T. P. Z. (2013). Identifikasi Penggunaan Formalin Pada Ikan Asin Dan Faktor Perilaku Penjual Di Pasar Tradisional Kota Semarang. Unnes Journal of Public Health, 2(3), 1-10. DOI: https://doi.org/10.15294/UJPH.V2I3.3031

10. Girsang, D. Y., Rangga, A., \& Susilawati. (2014). Kasus distribusi dan penggunaan formalin dalam pengawetan komoditi ikan laut segar (studi kasus di kota Bandar Lampung). Jurnal Teknologi Dan Industri Hasil Pertanian, 19(3), 218-228. DOI: https://doi.org/10.1186/1475-2875-12-4

11. Yiu, P. H., See, J., Rajan, A., \& Bong, C. F. J. (2008). Boric acid levels in fresh noodles and fish ball. American Journal of Agricultural and Biological Science, 3(2), 476-481. DOI: https://doi.org/10.3844/ajabssp.2008.476.481

12. Suryadi, H., Kurniadi, M., \& Melanie, Y. (2010). Analisis Formalin Dalam Sampel Ikan Dan Udang Segar Dari Pasar Muara Angke. Majalah IImu Kefarmasian, VII(3), 16-31. DOI: http://dx.doi.org/10.7454/psr.v7i3.3458

13. Norliana, S., Abdulamir, A. S., Bakar, F. A. and, \& Salleh, A. B. (2009). The Health Risk of Formaldehyde to Human Beings. American Journal of Pharmacology and Toxicology, 4(3), 98-106. DOI: http://dx.doi.org/10.3844/ajptsp.2009.98.106

14. Sanyal, S., Sinha, K., Saha, S., \& Banerjee, S. (2017). Formalin in fish trading: an inefficient practice for sustaining fish quality. Archives of Polish Fisheries, 25(1), 4350. https://doi.org/10.1515/aopf-2017-0005

15. Hastuti, S. (2010). Analisis kualitatif dan kuantitatif formaldehid pada ikan asin di madura. AGROINTEK, 4(2), 132-137. DOI: http://dx.doi.org/10.21107/agrointek.v4i2.1366

16. Astuti, E. D., \& Nugroho, W. S. (2017). Kemampuan Reagen Curcumax Mendeteksi Boraks dalam Bakso yang Direbus. Jurnal Sain Veteriner, 35(1), 42. DOI: https://doi.org/10.22146/jsv.29289

17. Das, U. narayan, Jana, P., Dhanabalan, V., \& Xavier, K. A. M. (2018). Detection of Formaldehyde Content in Selected Fish from Three Different Retail Markets at Mumbai. International Journal of Current Microbiology and Applied Sciences, 7(11), 2316-2322. DOI: https://doi.org/10.20546/ijcmas.2018.711.261

18. Google Map. (2017). Aplikasi Google Maps. http://maps.google.com/

19. Littay, C., Wisudo, S. H., Haluan, J., \& Harianto, B. (2017). Pengaruh Perbedaan Metode Pendinginan Dan Waktu Penyimpanan Terhadap Mutu Organoleptik Ikan Cakalang Segar. Jurnal IImu Dan Teknologi Kelautan Tropis, 9(2), 717-726. DOI: https://dx.doi.org/10.29244/jitkt.v9i2.19304

20. Nugroho, T. A., Kiryanto, \& Adietya, B. A. (2016). Kajian Eksperimen Penggunaan Media Pendingin Ikan Berupa Es basah dan Ice Pack sebagai Upaya Peningkatan Performance Tempat Penyimpanan Ikan Hasil Tangkapan Nelayan. Jurnal Teknik Perkapalan, $4(4)$, 889-898 https://ejournal3.undip.ac.id/index.php/naval/article/download/14800/14320 
